\title{
Evapotranspiration of a declining Quercus robur (L.) stand from 1999 to 2001. II. Daily actual evapotranspiration and soil water reserve
}

\author{
Caroline VINCKE ${ }^{\mathrm{a} *}$, André GRANIER ${ }^{\mathrm{b}}$, Nathalie BREDA ${ }^{\mathrm{b}}$, Freddy DEVILLEZ $^{\mathrm{a}}$ \\ ${ }^{a}$ Unité des Eaux et Forêts, Faculté d'ingénierie biologique, agronomique et environnementale, Université Catholique de Louvain, \\ Croix du Sud, 2/9, 1348 Louvain-la-Neuve, Belgium \\ b Équipe bioclimatologie-Ecophysiologie, INRA, Centre de recherches de Nancy, 54280 Champenoux, France
}

(Received 15 November 2004; accepted 2 March 2005)

\begin{abstract}
The components of actual evapotranspiration (ET) - interception (In\%), tree transpiration (T) and forest floor ET - were measured from 1999 to 2001 in a mixed stand dominated by declining pedunculate oaks. Sap flux density measurements (oaks and maple) and forest floor ET [38] were extrapolated to season and stand scales by regressions with potential evapotranspiration (PET) and leaf area index (LAI). Stand ET varies between 383 and $594 \mathrm{~mm}$ (ET/PET: 0.75-1.23). Oak transpiration (21-38\% of stand transpiration) is lower than forest floor ET: forest floor can therefore not be neglected in this stand water balance. The soil water reserve dynamics deduced from those measurements reflects the inter-annual changes of water use. No water stress have been calculated on the 1999-2001 period, but it is suspected to have occurred previously; together with soil constraints and caterpillar defoliation, it could in part explain the severe oak decline symptoms.
\end{abstract}

transpiration / evapotranspiration / Quercus robur (L.) / forest decline / soil water reserve

Résumé - Évapotranspiration d'un peuplement de chêne pédonculé (Quercus robur L.) dépérissant, de 1999 à 2001 . II. Évapotranspiration réelle et réserve en eau du sol journalières. Les composantes de l'évapotranspiration réelle (ETR) - interception (In\%), transpiration (T) des arbres et évapotranspiration du sous-étage herbacé - ont été mesurées de 1999 à 2001 dans un peuplement mélangé, dominé par du chêne pédonculé dépérissant. Les densités de flux de sève (chêne et érable) et l'évapotranspiration du sous-étage herbacé [38] ont été extrapolées à l'échelle de la saison et du peuplement par des régressions avec l'évapotranspiration potentielle (ETP) et l'indice foliaire (LAI). L'ETR du peuplement varie de 383 à 594 mm (ETR/ETP: 0.75-1.23). La transpiration du chêne (21-38\% de la transpiration du peuplement) est beaucoup plus faible que celle de la strate herbacée: cette strate ne peut dès lors pas être négligée dans le calcul du bilan hydrique de ce peuplement à plusieurs strates. La dynamique de la réserve en eau du sol, déduite de ces mesures, reflète les changements inter-annuels d'utilisation de l'eau par le peuplement. Aucun stress hydrique n'a été calculé sur la période 1999-2001, mais ce facteur est suspecté d'avoir joué un rôle dans les années antérieures; avec les contraintes édaphiques et les défoliations de chenilles, ce facteur pourrait en partie expliquer le dépérissement observé.

transpiration / évapotranspiration / Quercus robur (L.) / dépérissement forestier / réserve en eau du sol

\section{INTRODUCTION}

The estimation of forest water use, i.e. actual evapotranspiration $(\mathrm{ET})$, is the subject of numerous researches in a wide range of disciplines [42]. Several methodologies are available and their use depends on the spatial and temporal scale, the components of ET and the level of complexity that are needed [41]. One of the methods consists in measuring separately each components of ET, i.e. canopy interception, plant transpiration and soil evaporation. This gives insights into the ecosystem ecophysiology. In order to encompass a spectrum of contrasted conditions, records of forest water use during several years are necessary [29]. By proceeding in such a way, analysis of the possible disturbances of water cycle, as a consequence of a thinning, a decline or pathogens attack can be achieved. Once ET is estimated, soil water reserve daily variations can be calculated. Effectively, the water balance method deduces soil water reserve of day $\mathrm{i}\left(\mathrm{R}_{\mathrm{i}}, \mathrm{mm} \mathrm{d}^{-1}\right)$ by adding rainfall $\left(\mathrm{P}_{\mathrm{i}}\right)$ and by subtracting actual evapotranspiration $\left(\mathrm{ET}_{\mathrm{i}}\right)$ and surface runoff from water reserve of day (i-1).

The present study, through water balance estimation, presents measurements of water use in two plots contrasted in density in a mixed broad-leaved stand dominated by declining 100 -years-old pedunculate oaks. In both plots, oak LAI is low $(<3)$ and canopies structure is heterogeneous. Oak leaves are mostly organised in clusters in the crown or developed on

\footnotetext{
* Corresponding author: vincke@efor.ucl.ac.be
} 
Table I. For each year and each plot (Th.: Thinned; C.: Control): (a) basal area (G, $\left.\mathrm{m}^{2} \mathrm{ha}^{-1}\right)$, LAI and sapwood area (SA, $\mathrm{m}^{2}$ ha $\left.{ }^{-1}\right)$ of pedunculate oak, maple, ring- and diffuse porous species (ring porous species: Quercus robur, Quercus rubra, Fraxinus excelsior; diffuse porous species: Acer pseudoplatanus, Prunus avium, Betula sp., Crataegus sp., Carpinus betulus and Fagus sylvatica). Total per treatment is indicated (in $\mathrm{m}^{2} \mathrm{ha}^{-1}$ for G and SA, in $\mathrm{m}^{2} \mathrm{~m}^{-2}$ for LAI); (b) proportion of ring- and diffuse porous species in basal area in 1999 (\%G), in LAI (\%LAI) and in sapwood area (\%SA).

\begin{tabular}{|c|c|c|c|c|c|c|c|c|c|c|c|c|}
\hline \multirow[t]{3}{*}{ (a) } & \multicolumn{2}{|c|}{ G } & \multicolumn{6}{|c|}{ LAI } & \multicolumn{4}{|c|}{ SA } \\
\hline & Th. & C. & & Th. & & & C. & & Th. & & C. & \\
\hline & \multicolumn{2}{|c|}{1999} & 1999 & 2000 & 2001 & 1999 & 2000 & 2001 & 1999-2001 & 1999 & 2000 & 2001 \\
\hline Q. robur $\mathrm{L}$. & 13.8 & 20.9 & 2.8 & 1.9 & 2.45 & 2.8 & 2.3 & 2.45 & 3.2 & 4.2 & 4.1 & - \\
\hline Acer & 1.7 & 2.24 & 0.2 & 0.12 & - & 0.42 & 0.9 & - & 0.24 & 1.45 & - & - \\
\hline Ring porous & 15.5 & 24.9 & 3.28 & 2.98 & - & 3.42 & 3.7 & - & 3.9 & 6.3 & 6 & 5.8 \\
\hline Diffuse porous & 1.9 & 3.5 & 0.32 & 0.12 & - & 0.88 & 1.3 & - & 0.4 & 2.6 & 2.6 & 2.6 \\
\hline Total & 17.4 & 28 & 3.6 & 3.1 & 3.5 & 4.3 & 3.7 & 4.2 & 4.32 & 8.9 & 8.6 & 8.4 \\
\hline \multirow[t]{3}{*}{ (b) } & \multicolumn{2}{|c|}{$\% \mathrm{G}$} & \multicolumn{6}{|c|}{$\%$ LAI } & \multicolumn{4}{|c|}{$\% \mathrm{SA}$} \\
\hline & Th. & C. & & Th. & & & C. & & Th. & & C. & \\
\hline & \multicolumn{2}{|c|}{1999} & 1999 & 2000 & 2001 & 1999 & 2000 & 2001 & 1999-2001 & 1999 & 2000 & 2001 \\
\hline Ring porous & 89 & 84 & 92.6 & 93.7 & - & 79 & 66.5 & - & 91 & 70.9 & 70.1 & 69.2 \\
\hline Diffuse porous & 11 & 16 & 7.4 & 6.3 & - & 21 & 33.5 & - & 9 & 29.1 & 29.9 & 30.7 \\
\hline
\end{tabular}

epicormic branches. Also, large gaps through the canopy led to the development of an abundant herbaceous cover [37]. Such a complexity in stands structure needed appropriate methodology to estimate water use.

The main objective of this paper is to estimate these plots actual evapotranspiration (ET) on a daily time step. It was therefore needed to: (i) estimate canopies water interception, (ii) detail tree (oak and secondary species) and herbaceous water use on a daily basis and (iii) quantify soil water reserve dynamic. Intra- and inter-annual changes will be commented as well as differences between plots. Drought risk occurrence will be discussed, through the estimation of the Relative Extractable Water (REW) of the soil. Effectively, several studies demonstrated that a soon as REW decreased below a threshold of about 0.4 , the soil water becomes limiting for tree transpiration $[6,12,34]$.

\section{MATERIALS AND METHODS}

\subsection{Environmental settings}

The study area is located in the south of Belgium. Climate is humid temperate with mean annual precipitation of $960 \mathrm{~mm}$ and mean temperature of $8.4^{\circ} \mathrm{C}$. Soils are dystric Cambisol [10]. Those soils present severe signs of hydromorphy: a temporary ground water table is present from late fall to late spring [39]. The forest stand is dominated by Quercus robur L., with also Fraxinus excelsior L., Quercus rubra L., Betula sp., Acer pseudoplatanus L. The forest floor vegetation is constituted mainly by Circaea lutetiana L., Stachys sylvatica L., Carex pendula Huds., Athyrium filix femina (L.) Roth and Rubus fruticosus L., the latest being the most covering. In the control plot, Prunus spinosa $\mathrm{L}$. shrubs are found in patches. Herbaceous LAI reached values of 2.5 in the thinned plot and 2 in the control one.

\subsection{Experimental design and environmental monitoring}

The experimental design is fully described in this article's companion [38]. In 2001, below canopy global radiation $\left(\mathrm{Rg}_{\mathrm{bc}}, \mathrm{W} \mathrm{m}^{-2}\right)$ was measured every 2 -min in each plot with two tube solarimeter TSL (INRA) horizontally fixed at $1.5 \mathrm{~m}$ above the soil surface, in an E-W direction. That same year, below canopy Photosynthetic Active Radiation $\left(\mathrm{PAR}_{\mathrm{bc}}, \mu \mathrm{mol} \mathrm{m} \mathrm{m}^{-2} \mathrm{~s}^{-1}\right)$ was manually measured every hour during 4 days (Day Of Year: DOY 192-213-241-284), at 10 locations grid in each plot with the Sunscan Canopy Analysis System (Delta-T, Cambridge, UK).

An automatic weather station (PAMESEB, Libramont, Belgium) monitored hourly the local climate at $1 \mathrm{~km}$ from the stand. Potential evapotranspiration (PET, mm) was calculated according to the Penman formula [28].

Throughfall was measured in two ways. From 1999 to 2001, two automatic tipping bucket rain gauges (GME PR12, GME, Incourt, Belgium) were installed in each plot at $1.5 \mathrm{~m}$ above soil surface; each couple of rain gauge was connected to an Easylog DL (GME, Incourt, Belgium). They recorded every rain event and summed them at a halfhour basis. In addition, 15 rain gauges evenly distributed along the 3 inner lines in each plot were used in 2000 and 2001 to estimate spatial variability of throughfall; water collection was realised once a week. The understorey also intercepts throughfall; this term was not measured here but Schnock [33] estimated this interception in several deciduous forests, as 1 to $12 \%$ of rainfall. Stemflow was not measured as well because different studies $[1,16,27]$ found it to be very low in oak stands $(<1 \%$ of total precipitation), mainly because of the rough and moss-covered bark and branches.

Ring-porous sapwood area $\left(\mathrm{SA}, \mathrm{m}^{2}\right)$ was estimated on the basis of the in situ relationship established between oak SA and circumference at breast-height $(\mathrm{CBH}, \mathrm{cm})$ :

$$
\mathrm{SA}=0.00022 \times \mathrm{CBH} \quad R^{2}=0.5308 .
$$

Diffuse-porous species SA was estimated with the same relationship than for maple, given in Mathieu [24].

Table I summarises each plot's basal area, LAI and SA for the 3 years and for each type of species. Total LAI was estimated from litter 
1999

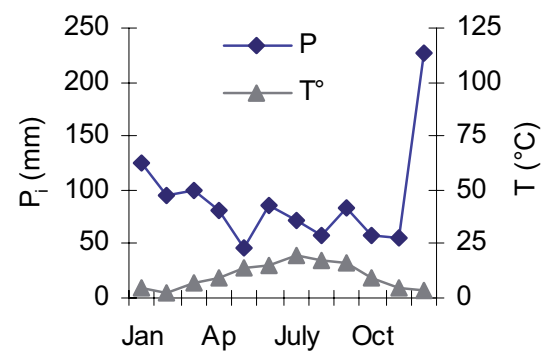

2000

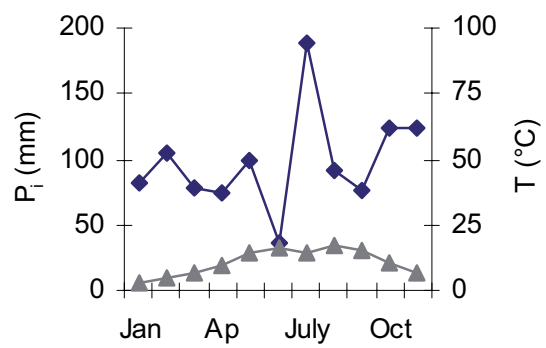

2001

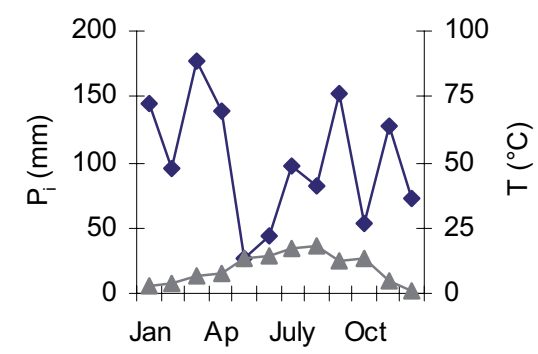

Figure 1. Gaussen ombrothermic diagrams for 1999, 2000 and 2001, on the basis of Pameseb measurements: incident rain $\left(P_{i}\right)$ and mean air temperature $\left({ }^{\circ} \mathrm{C}\right)$ as functions of months.

collection during fall in 10 litter traps in each plot $\left(0.49 \mathrm{~m}^{2}\right.$ per trap). For each trap, leaves from the different tree species were separated and dried $\left(48 \mathrm{~h}, 80^{\circ} \mathrm{C}\right)$. Every two weeks, and before being dried, 20 randomly selected leaves of each species were surfaced with a video camera coupled with an image analysis system (Semper 6P, Synoptics Limited). This was done to measure SLA (Specific Leaf Area, $\mathrm{cm}^{2} \mathrm{~g}^{-1}$ ), which was then multiplied by total dry weight to calculate total foliar surface $\left(\mathrm{FS}, \mathrm{cm}^{2}\right)$. Total LAI was derived from FS and litter traps sampling intensity. LAI seasonal time course was measured with the LAI2000 Plant Canopy Analyser (Li-Cor, Lincoln, NE, USA), extensively described by Welles and Norman [40]. Caterpillar (Tortrix viridina L.) defoliation was observed every year during leaves budding.

Soil water balance is expressed with the following water balance equation:

$$
R_{i}=R_{i-1}+P_{i}-E T_{i}
$$

where $R_{i}$ is soil water reserve of day $i(m m), R_{i-1}$ is soil water reserve of day (i-1), $\mathrm{P}_{\mathrm{i}}$ is day i rainfall $(\mathrm{mm})$ and $\mathrm{ET}_{\mathrm{i}}$ is total stand evapotranspiration losses of day $\mathrm{i}(\mathrm{mm})$, i.e. the sum of tree and understorey transpiration, soil evaporation and rain interception. This calculation was made in condition of no drainage (a poorly weathered schist stratum, located at 1.7-2.1 m depth, strongly reduces drainage and contributes to the formation of the water table during autumn and winter; [39]).

\section{RESULTS}

\subsection{Incident climate and forest interception on climate variables}

Gaussen's ombrothermic diagrams for the three years of this study (Fig. 1) show that May and June are often drier than the other months; nevertheless, no climatic drought $\left(\mathrm{P}<2 \times \mathrm{T}^{\circ}\right)$ was monitored during the 3 years. In 1999, rainfall was well distributed throughout the growing season, excepted in May and August. In 2000, July was particularly wet whereas in 2001 it was September. During the 3 years, significant dry periods (10-15 days) occurred between DOY 117-126, 204-217 and 239-248 in 1999, DOY 159-172 and 262-271 in 2000 and DOY 125-133 and 139-151 in 2001. For leafy periods (DOY 91-304), rainfall was $481 \mathrm{~mm}$ in 1999, $688 \mathrm{~mm}$ in 2000, $593 \mathrm{~mm}$ in 2001. Over the 1971-2001 period, the normal precipitation was 552 mm. 1999 was therefore the driest year and 2000 the wettest.

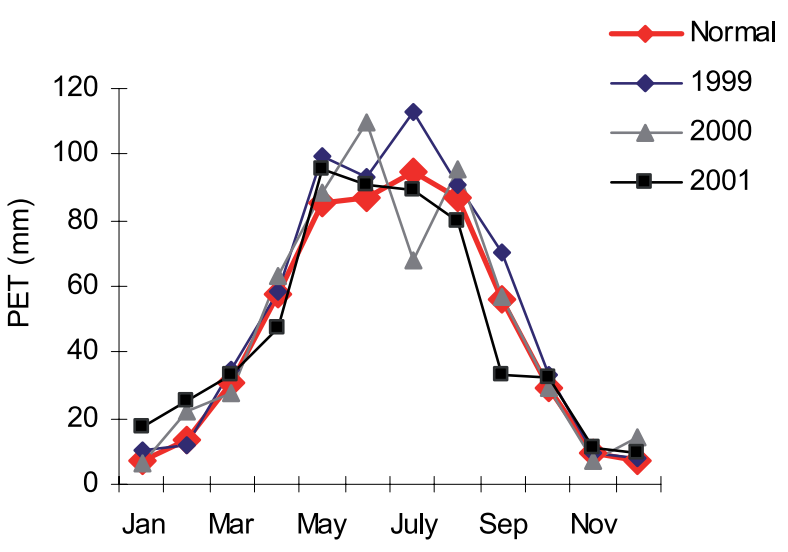

Figure 2. Monthly normals of PET (average of each month over the 1971-2001 period) and average monthly PET for 1999, 2000 and 2001.

Potential evapotranspiration (PET) was high from May to July 1999 (Fig. 2). From 1999 to 2001, cumulative PET over the leafy periods was 510, 484 and $468 \mathrm{~mm}$ (Tab. IV).

As only 2 tipping buckets could not provide an accurate measurement of throughfall due to its high spatial variability within the plots, we first established the relationships between both types of measurements (tipping buckets and rain gauges; Tab. II). These relationships were applied to tipping buckets daily values, to estimate rainfall interception (In\%). In\% during the leafy periods was always higher in the control plot, with the strongest difference observed in 2000 (Tab. III). Daily In\% varied between 18.2 and $27.7 \%$ in the thinned plot and between 22.3 and $43.4 \%$ in the control plot. In the thinned plot, In\% during winter 2000-2001 is similar between leafy and non-leafy periods, which is probably a consequence of a lack of data due to electronic breakdown. During leafy periods, throughfall amounts were $350.3,491$ and $456.6 \mathrm{~mm}$ in the thinned plot for 1999, 2000 and 2001 respectively. In the control plot, it reached 339, 380 and $433 \mathrm{~mm}$. The relationship between LAI and In\% is shown on Figure 3. As the LAI amplitude is low, especially in the thinned plot, no clear tendency can be pointed out. 
Table II. Rainfall measured with the tipping buckets $\left(\mathrm{P}_{\mathrm{tp}}\right)$ as a function of the measurements with rain gauges $\left(\mathrm{P}_{\mathrm{rg}}\right)$, to incorporate spatial variability.

\begin{tabular}{cllll}
\hline & & \multicolumn{2}{c}{ Leafy period } & Non leafy period \\
\hline Th. & 2000 & $\mathrm{P}_{\mathrm{tp}}=1.0014 \times \mathrm{P}_{\mathrm{rg}}$ & $R^{2}=0.8986$ & $\mathrm{P}_{\mathrm{tp}}=0.8844 \times \mathrm{P}_{\mathrm{rg}} \quad R^{2}=0.9166$ \\
& 2001 & $\mathrm{P}_{\mathrm{tp}}=0.8602 \times \mathrm{P}_{\mathrm{rg}}$ & $R^{2}=0.869$ & $\mathrm{P}_{\mathrm{tp}}=0.7757 \times \mathrm{P}_{\mathrm{rg}} \quad R^{2}=0.8543$ \\
C. & 2000 & $\mathrm{P}_{\mathrm{tp}}=0.9167 \times \mathrm{P}_{\mathrm{rg}}$ & $R^{2}=0.87$ & \\
\hline
\end{tabular}

Table III. Rain interception (In, \%) in leafy and non leafy periods for the 3 years of measurements and for each plot (Th.: Thinned; C.: Control). Values are tipping buckets hourly measurements summed per day and corrected with equations from Table II.

\begin{tabular}{lccccc}
\hline \multirow{2}{*}{ Year } & \multicolumn{2}{c}{ Leafy period } & & \multicolumn{2}{c}{ Non leafy period } \\
\cline { 2 - 3 } \cline { 5 - 6 } & Th. & C. & & Th. & C. \\
\hline 1999 & 24.3 & 26.1 & & 19.6 & 22.9 \\
2000 & 27.7 & 43.4 & & 25.5 & 24.9 \\
2001 & 18.2 & 22.3 & & 19.9 & 19.9 \\
\hline
\end{tabular}

Global radiation measurements $\left(\mathrm{W} \mathrm{m}^{-2}\right)$ above $\left(\mathrm{Rg}_{\mathrm{o}}\right)$ and below $\left(\mathrm{Rg}_{\mathrm{bc}}\right)$ canopy demonstrated the following relationships:

Leafy period

$$
\begin{array}{lll}
\text { (Th.) } & \mathrm{Rg}_{\mathrm{bc}}=0.1429 \times \mathrm{Rg}_{\mathrm{o}} & R^{2}=0.76 \\
\text { (C.) } & \mathrm{Rg}_{\mathrm{bc}}=0.1164 \times \mathrm{Rg}_{\mathrm{o}} & R^{2}=0.81
\end{array}
$$

Non-leafy period

$$
\begin{array}{lll}
\text { (Th.) } & \mathrm{Rg}_{\mathrm{bc}}=0.1637 \times \mathrm{Rg}_{\mathrm{o}} & R^{2}=0.81 \\
\text { (C.) } & \mathrm{Rg}_{\mathrm{bc}}=0.1473 \times \mathrm{Rg}_{\mathrm{o}} & R^{2}=0.88 .
\end{array}
$$

During the leafy period, below canopy Photosynthetically Active Radiation $\left(\mathrm{PAR}_{\mathrm{bc}}, \mu \mathrm{mol} \mathrm{m} \mathrm{m}^{-2} \mathrm{~s}^{-1}\right.$ ) was related to $\mathrm{Rg}_{\mathrm{bc}}$ by the following relationships:

$$
\begin{array}{lll}
\text { (Th.) } & \mathrm{PAR}_{\mathrm{bc}}=1.7445 \times \mathrm{Rg}_{\mathrm{bc}} & R^{2}=0.59 \\
\text { (C.) } \quad \mathrm{PAR}_{\mathrm{bc}}=0.612 \times \mathrm{Rg}_{\mathrm{bc}} & R^{2}=0.16 .
\end{array}
$$

\subsection{Gap filling for tree transpiration (T)}

Sapflow measurements [38] used to calculate oak and maple (daily) transpiration, had to be estimated when measurements were lacking due to electric breakdown or maintenance stop. The gaps were filled by several ways according to leaf area development. For periods of leaf area expansion and leaf fall, daily transpiration was calculated with an equation based on daily PET and on a relative LAI ( $\left.\mathrm{LAI}_{\mathrm{i}} / \mathrm{LAImax}\right)$, with i standing for the day and LAImax standing for the maximum LAI of the year. For periods of constant LAI, oak transpiration was deduced by interpolation (1 missing day). If data were lacking for a tree during several consecutive days, the slope of the regression between PET and transpiration of an oak of same SA was used to rebuild the series.

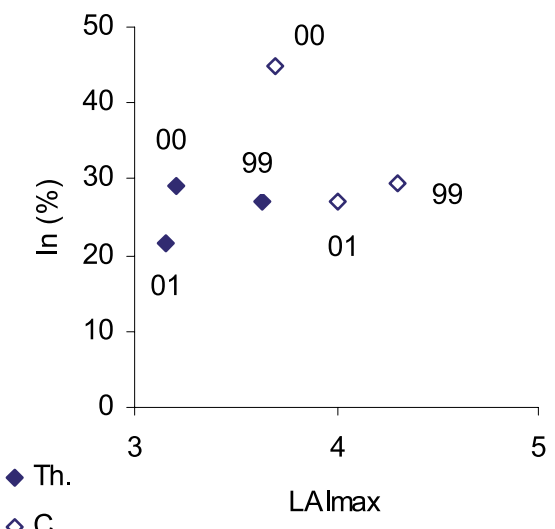

Figure 3. Rainfall interception during the leafy period (In\%, calculated with tipping buckets measurements corrected by equations of Tab. II) for 1999, 2000, 2001 as a function of LAImax for each plot (Th.: Thinned; C.: Control).

Transpiration of ring-porous species was then estimated as follows:

$$
\mathrm{T}_{\mathrm{rp}}=\mathrm{T}_{\mathrm{oak}} \times \mathrm{SA}_{\mathrm{rp}} / \mathrm{SA}_{\mathrm{oak}}
$$

with SA in $\mathrm{m}^{2} \mathrm{ha}^{-1}$.

For diffuse porous species, maple SFD measurements were used to estimate $T_{d p}$ on the basis of their SA in each plot. In the control plot, $\mathrm{T}_{\mathrm{dp}}$ was dependent of PET:

$$
\mathrm{T}_{\mathrm{dp}}=0.14878 \times \mathrm{PET} \quad R^{2}=0.63 .
$$

This relationship was used to fill gaps on periods with identical LAI. For leaf expansion periods and leaf fall, the same methods than for oaks have been used. In the thinned plot, maple transpiration didn't give acceptable results because of technical breakdown, so diffuse porous species transpiration was calculated as follows:

$$
\mathrm{T}_{\mathrm{dp}(\mathrm{E})}=0.14878 \times \mathrm{PET} \times \mathrm{SA}_{\mathrm{dp}(\mathrm{Th})} / \mathrm{SA}_{\mathrm{dp}(\mathrm{C})} .
$$

Those reconstitution give the daily variation of transpiration for oak, ring- and diffuse-porous species from 1999 to 2001 (Fig. 4). Oak and ring porous time course look similar, excepted for the maxima, which are raised by 0.3 to $0.4 \mathrm{~mm} \mathrm{~d}^{-1}$ among plots. On the contrary, diffuse porous species transpiration showed large differences among treatments. In the thinned plot, it never exceeded $0.15 \mathrm{~mm} \mathrm{~d}^{-1}$, whereas in the control plot it varied between 0.5 and $0.98 \mathrm{~mm} \mathrm{~d}^{-1}$. Whereas diffuse porous 

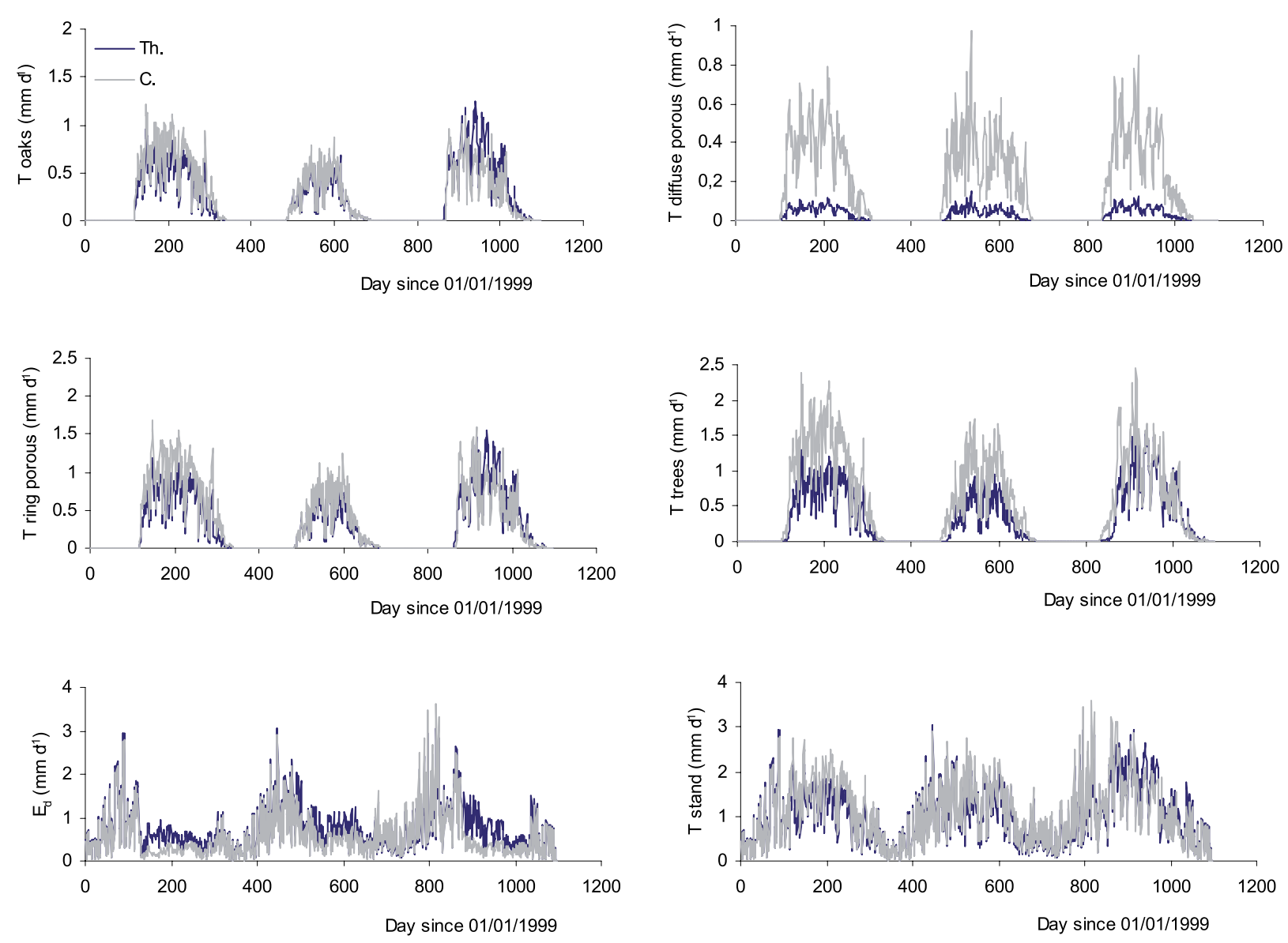

Figure 4. Daily transpiration $\left(\mathrm{T}, \mathrm{mm} \mathrm{d}^{-1}\right)$ for oak, ring- and diffuse-porous species, trees, forest floor $\left(\mathrm{E}_{\mathrm{d}}\right)$ and stand, in 1999,2000 and 2001.

species occur in almost the same proportion in each plot in terms of basal area contribution (Th.: $11 \%$; C.: 16\%), they contribute to about $30 \%$ of LAI and SA in the control plot, and only to $6-9 \%$ of those parameters in the thinned plot. When considering all trees, in 1999 and in 2000 the control plot's transpiration is 0.35 the thinned plot's; in 2001, it is 0.20 (excepted for budbreak period).

\subsection{Simulations of daily forest floor transpiration $\left(E_{d}\right)$}

The forest floor transpiration was dependent upon LAI and PAR $_{\mathrm{bc}}$ [38]. Daily forest floor transpiration $\left(\mathrm{E}_{\mathrm{d}}, \mathrm{mm} \mathrm{d} \mathrm{d}^{-1}\right.$, Fig. 4), was therefore simulated with the following equations:

$$
\mathrm{E}_{\mathrm{d}}=(-0.858 \times \mathrm{LAI}+4.001) \times f\left(\mathrm{PAR}_{\mathrm{bc}}\right)
$$

with

$$
f\left(\mathrm{PAR}_{\mathrm{bc}}\right)=\mathrm{PAR}_{\mathrm{bci}} / \mathrm{PAR}_{\mathrm{bcmax}}
$$

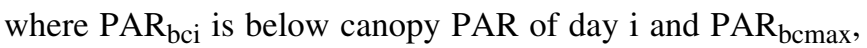
the maximal below canopy PAR; both are deduced from equation (3) to (8). Each year, a different value of PAR bcmax $_{\text {was }}$ taken for the leafy and non-leafy periods. During the leafless period, LAI is fixed to 1.1 in the thinned plot and 1.3 in the control plot, which are in fact the WAI values (Wood Area Index) presented in Vincke [37]. The results (Fig. 4) showed that before tree budbreak, forest floor transpiration is almost identical in both plots, with maxima of $2.2 \mathrm{~mm} \mathrm{~d}^{-1}$ in $1999,2.3 \mathrm{~mm} \mathrm{~d}^{-1}$ in 2000 and $2.9 \mathrm{~mm} \mathrm{~d}^{-1}$ in 2001. After, it is depending upon LAI and PAR evolution as a direct result of the calculation. As forest floor transpiration measurements were held on one location in each plot, its dependency upon LAI was used to estimate its spatial variability and differences between plots (Fig. 5). On each LAI measurements location (15 per plot), $E_{d}$ was calculated with equation (14), cited in [38]:

$\mathrm{E}_{\mathrm{d}}(\mathrm{mm})=-0.9574 \times \mathrm{LAI}+4.3701 R^{2}=0.8215$.

Standard deviation from the LAI-based estimation is smaller in the control plot, which canopy is more homogeneous. Effectively, only $10 \%$ of this canopy is constituted by gaps, against $27 \%$ in the thinned plot [37]. Those canopy features differences led to a forest floor development and transpiration different among plots.

\subsection{Water use in each plot: $T$ and $E T$}

$\mathrm{T}$ and ET in each plot, for each year and each canopy layer are summarised in Table IV. Stand transpiration in both plots 
Table IV. For each plot (Th.: Thinned; C.: Control), potential evapotranspiration (PET, mm), transpiration (T, mm), actual evapotranspiration $(\mathrm{ET}, \mathrm{mm}$ ) for the stand; trees transpiration, forest floor transpiration and proportion in total ET (\%ET); pedunculate oak transpiration (Oak) and proportion in total ET (\%ET); ring- and diffuse-porous transpiration, from DOY 91 to DOY 304 in 1999, 2000 and 2001.

\begin{tabular}{|c|c|c|c|c|c|c|c|c|c|c|c|c|c|c|c|c|}
\hline \multirow[t]{2}{*}{ Year } & \multirow[t]{2}{*}{ Plot } & \multirow[t]{2}{*}{ PET } & \multicolumn{3}{|c|}{ Stand } & \multicolumn{2}{|c|}{ Trees } & \multicolumn{2}{|c|}{ Forest floor } & \multicolumn{2}{|c|}{ Oak } & \multirow{2}{*}{$\begin{array}{c}\begin{array}{c}\text { Ring- } \\
\text { Porous }\end{array} \\
\mathrm{T}\end{array}$} & \multirow{2}{*}{$\begin{array}{c}\begin{array}{c}\text { Diffuse- } \\
\text { Porous }\end{array} \\
\mathrm{T}\end{array}$} & \multirow{2}{*}{$\begin{array}{l}\text { Toaks/ } \\
\text { Tstand }\end{array}$} & \multirow{2}{*}{$\begin{array}{l}\text { Therbs/ } \\
\text { Tstand }\end{array}$} & \multirow{2}{*}{$\begin{array}{l}\text { Ttrees/ } \\
\text { Therbs }\end{array}$} \\
\hline & & & $\mathrm{T}$ & ET & ET/ PET & $\mathrm{T}$ & $\%$ ET & $\mathrm{T}$ & $\% \mathrm{ET}$ & $\mathrm{T}$ & $\% \mathrm{ET}$ & & & & & \\
\hline \multirow[t]{2}{*}{1999} & Th. & 510 & 252 & 383 & 0.75 & 128 & 0.33 & 124 & 0.32 & 91.6 & 0.24 & 118 & 10 & 0.36 & 49.3 & 1.03 \\
\hline & C. & & 311 & 453 & 0.89 & 233 & 0.51 & 78 & 0.17 & 119 & 0.26 & 166 & 67 & 0.38 & 25.2 & 2.98 \\
\hline \multirow[t]{2}{*}{2000} & Th. & 484 & 248 & 449 & 0.93 & 74 & 0.16 & 175 & 0.39 & 51.6 & 0.11 & 65 & 9 & 0.21 & 70.2 & 0.42 \\
\hline & C. & & 282 & 594 & 1.23 & 149 & 0.25 & 133 & 0.22 & 59 & 0.10 & 84 & 65 & 0.21 & 47.3 & 1.11 \\
\hline \multirow[t]{2}{*}{2001} & Th. & 468 & 314 & 442 & 0.94 & 136 & 0.31 & 178 & 0.40 & 102 & 0.23 & 127 & 9.4 & 0.32 & 56.7 & 0.76 \\
\hline & $\mathrm{C}$. & & 297 & 458 & 0.98 & 179 & 0.39 & 118 & 0.26 & 80.7 & 0.18 & 117.3 & 62 & 0.27 & 39.7 & 1.52 \\
\hline
\end{tabular}

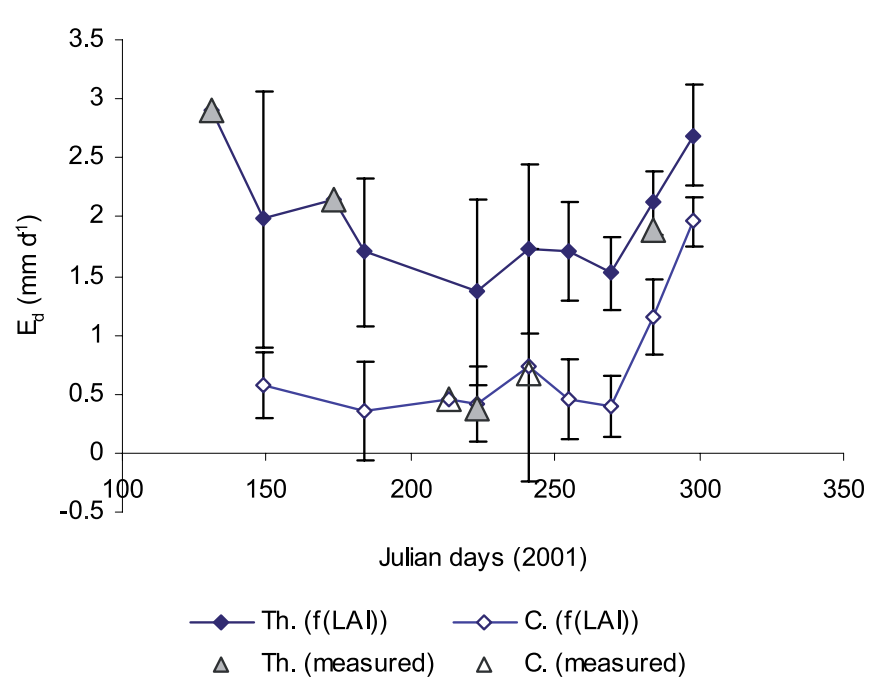

Figure 5. Forest floor transpiration $\left(\mathrm{E}_{\mathrm{d}}, \mathrm{mm} \mathrm{d}^{-1}\right)$ as measured with the closed chamber and as simulated with equation (14), for each plot (Th.: Thinned; C.: Control) in 2001 leafy period.

and for each year never exceeded $314 \mathrm{~mm}$. Oak transpiration (Tab. IV) is between $21 \%$ and $38 \%$ of stand transpiration. Ringporous transpiration is always higher than diffuse-porous, especially in the thinned plot. Trees transpire less water than forest floor in the thinned plot (excepted in 1999), with a minimum of $42 \%$ of forest floor ET in 2000. On the contrary, in the control plot, trees use three times more water than forest floor in 1999. From 1999 to 2001, total transpiration in the thinned plot relative to the control one increased from 81 to $106 \%$ (Tab. V). Excepted for 2001, tree transpiration in the thinned plot is about two third the transpiration in the control plot. But 2001 result could be an artefact of the variable number of functional flowmeters in the control plot. Oaks transpiration in the thinned plot increased (from 77 to $126 \%$ ), relatively to the control plot. Forest floor in the thinned plot always uses more water than in the control one (from 131 to $158 \%$ ). It seems to compensate what trees don't use. Diffuse porous trees water use is $85 \%$ lower in the thinned plot, as a direct effect of their lower representativeness.
Table V. For the stand, the trees, the forest floor (herbs), the pedunculate oaks (Oak), the ring- and the diffuse-porous species, the ratio between transpiration measured in the thinned plot and transpiration measured in the control plot (Th./C.).

\begin{tabular}{ccccccc}
\hline Year & Stand & Trees & Herbs & Oak & Ring-porous & Diffuse-porous \\
\hline 1999 & 0.81 & 0.65 & 1.58 & 0.77 & 0.71 & 0.15 \\
2000 & 0.88 & 0.66 & 1.31 & 0.87 & 0.78 & 0.13 \\
2001 & 1.06 & 0.79 & 1.51 & 1.26 & 1.08 & 0.15 \\
\hline
\end{tabular}

\subsection{Soil water reserve daily seasonal variations}

Using equation (2), daily variation of soil water reserve (Fig. 6) was calculated. Total soil water reserve (R, mm) was estimated by the mean of soil volumetric water content measurements (not shown) and was $600 \mathrm{~mm}$ out of excess water [37]. With the budding of most plants, soil water reserve decreases. A difference between plots is visible only in 1999 (starting DOY 209). Short-term variations are similar. It is also in 1999 that LAI between plots is the most contrasted. In the thinned plot, soil water depletion varied from $35.4 \mathrm{~mm}$ to $68.8 \mathrm{~mm}$ according years; in the control plot, it varied from 41.4 to $77.1 \mathrm{~mm}$. Minimum reserve $\left(\mathrm{R}_{\min }\right)$ is reached on DOY 256 (1999), 183 (2000) and 185 (2001). The extractable water (EW) was calculated on the basis of pF-curves and was $152 \mathrm{~mm}$ [39] over $160 \mathrm{~cm}$ depth. Relative extractable water (REW) was then calculated with the following equation:

$$
\mathrm{REW}_{\mathrm{i}}=\left(\mathrm{R}_{\mathrm{i}}-\mathrm{R}_{\mathrm{min}}\right) /(\mathrm{EW}) .
$$

$\mathrm{R}_{\min }$ is the minimum soil water reserve.

Variation of REW (Fig. 6b) showed the same dynamic than $\mathrm{R}$ but allowed to discuss the eventuality of water stress. REW never dropped below 0.4 , which indicates no water stress.

\section{DISCUSSION}

\subsection{Rainfall interception}

During the 3 years of measurements, no drought have been detected from estimated REW, even though in 1999 (P-PET) 

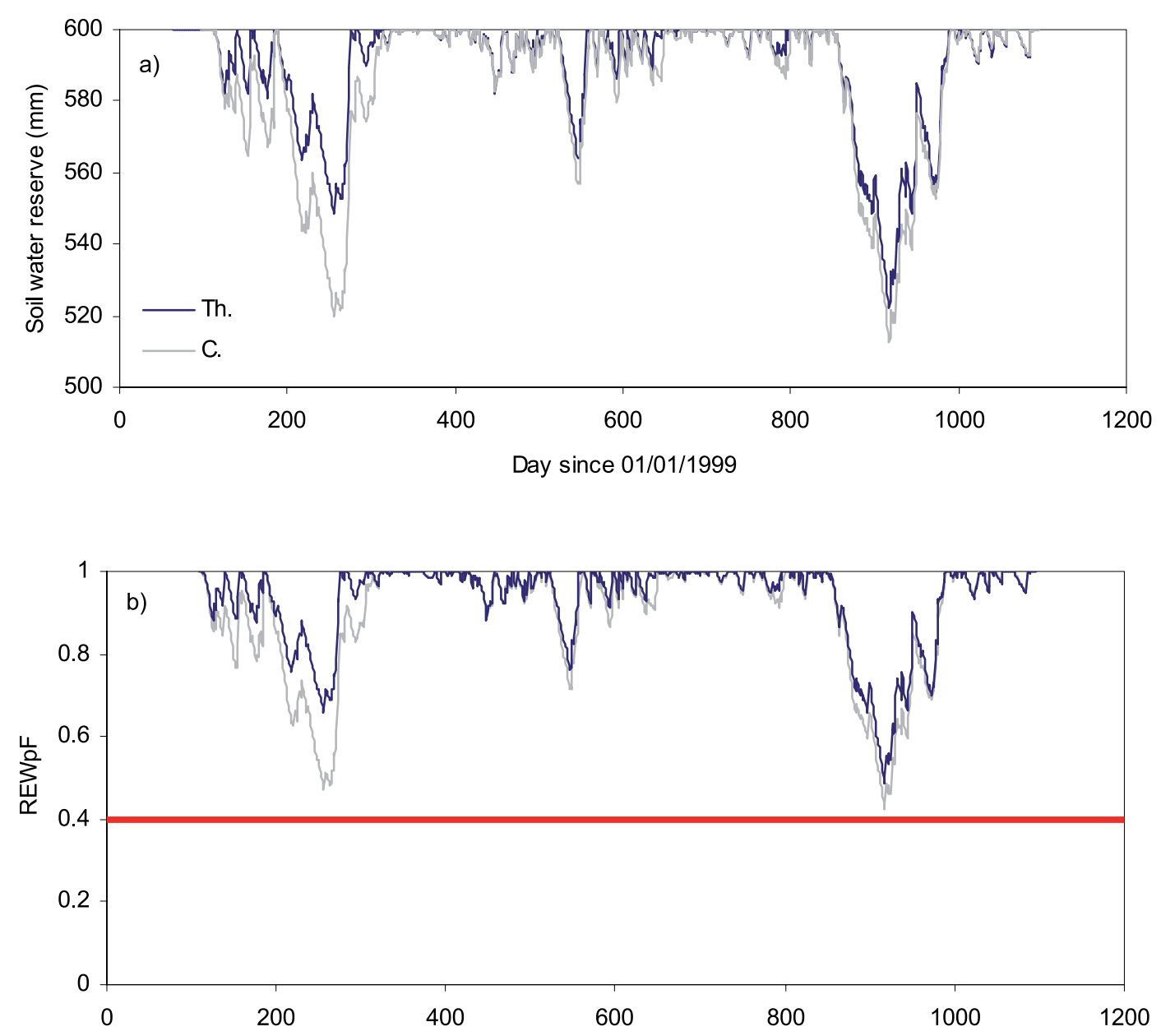

Figure 6. For each year and each plot (Th.: Thinned; C.: Control), (a) soil water reserve (mm) as deduced from equation (2); (b) relative extractable water calculated on the basis of an EW estimated by pF-curves (REWpF).

was deficitary $(-78 \mathrm{~mm})$ in leafy period, in particular in May $(-11.6 \mathrm{~mm})$ and July $(-32.5 \mathrm{~mm})$. Rainfall interception (In\%) during the leafy periods varied between $18 \%$ and $44 \%$ of incident rain according to the years. Nizinski and Saugier [27], in a 120 years old sessile oak stand estimated In\% from $28 \%$ to $41.2 \%$. Those values stand well with the ones cited in Aussenac [1], which varied from $20 \%$ to $40 \%$ for deciduous forests. The observed range is also close to data reported by Bréda et al. [8], who calculated In\% of $16-17 \%$ in a 35 years old sessile oak stand with LAI of 3.3. The intra- and inter-annual variations, not always well correlated with LAI, probably result from (i) the type of rain and (ii) climatic conditions; for instance, slight rains are almost totally intercepted. For a same amount of rain, In\% is also function of the evaporative demand (wind speed, radiation, vapour pressure deficit) and of the continuous or discontinuous pattern of the rain $[2,11,35]$.

\subsection{Over-and understorey evapotranspiration}

Sap flux density of individual trees can be extrapolated to stand by using relationship between sap flow and trees diame- ter, or basal area, or sapwood area or leaf area [36]. In mixed stands or when there is a pronounced hierarchy in vegetation structure, this approach can be applied to sub-groups of the population, by dividing stand in classes containing plants with similar characteristics [14]. We followed this approach by classifying trees according to their type of hydroactive xylem, i.e. in ring- and diffuse-porous species. SA was used as the reference scalar to extrapolate tree water use to stand water use.

Forest floor contributes greatly to ET in each plot, ranging from 0.75 to $3.1 \mathrm{~mm}$ per day in the thinned plot and from 0.3 to $3.6 \mathrm{~mm}$ per day in the control one. Forest floor ET represented up to $40.3 \%$ of ET in the thinned plot and up to $25.8 \%$ in the control plot. The relative contribution of forest floor transpiration is lower in the control plot, which is in accordance with Rutter [32], who observed that in closed canopies, only few energy was still available below canopy. Several authors emphasised the importance of forest floor transpiration in the water and carbon balances of forests $[7,9,15,22,26]$. For the water balance, Granier et al. [13] cited $30 \%$ for ferns in a Pinus pinaster stand and $10 \%$ for Vaccinium myrtillus below Pinus sylvestris. Forest floor contributed to 49 to $57 \%$ of stand 
transpiration for stands of Pinus radiata with a forest floor of Hypochaeris radicata L. and Holcus lanatus [19]. Lüttschwager et al. [23], in a 65 years old Pinus sylvestris stand measured a forest floor contribution (Deschampsia flexuosa) up to $50 \%$ of total water fluxes.

ET varied between 383 and $594 \mathrm{~mm}$ (years and plots confounded) with lower values in the thinned plot than in the control one; in 2001, ET of both plots were almost equal (Tab. IV). ET/PET varied from 0.75 to 1.23 for the stand. Ladekarl et al. [21] calculated a ET/PET ratio of 0.9 in deciduous forests. The T/PET was between 49 and $67 \%$ (plots and years confounded), which is in accordance with Wilson et al. [41], who measured a T/ET of $50 \%$ in a deciduous mixed irregular stand of oak and maple.

Following conclusions can be driven out: (i) 6-8 years after thinning, both plots use about the same amount of water besides different composition and structure and (ii) $\mathrm{T}$ (trees and understorey) is the main part of ET (excepted in 2000, very rainy year with low LAI).

Aussenac and Granier [3], showed also on Douglas-fir 5 years after thinning, that ET was similar in treated and non treated plots. It is possible that consequences of thinning on ET were important the 2-3 years after, as showed on Douglas-fir [4] and on oak [8]. Effectively, thinning usually implies a better water availability due to both lower $\mathrm{T}$ and $\mathrm{In}$, and, as a consequence, a diminution of length and intensity of water stress [3, 5, 25].

One of the most important findings is that oak transpiration is lower than herbaceous transpiration; when expressed as a function of ET, it varied from $10 \%$ to $26.6 \%$, which is low. Even if it is reasonable to state that forests developing more LAI would have higher transpiration rates, other proofs suggest that forest transpiration is a conservative hydrological process [18, 30]. One of the main causes is that understorey compensates the differences in loss of water from canopies with contrasted LAI. Our results confirm this hypothesis of a conservative use of water within forest, where transpiration tend to dampen more than to amplify the variations in evaporative demand or annual variations in water availability [17, 29]. Total stand transpiration during vegetation period is about $300 \mathrm{~mm}$ in both plots, even if there are big differences between them in their specific composition and structure. This is similar to the results of other studies [23, 29, 31]. Ladekarl [20] measured in a 150 years old Q. robur stand annual transpiration from 265 to $318 \mathrm{~mm}$.

\subsection{Soil water reserve and REW}

The soil of the study site can be considered as a lysimeter. The schist (at $180 \mathrm{~cm}$ depth), the clayed horizons and the flat topography induce the accumulation of water. Approximately, all water that penetrates the soil only gets out by evapotranspiration. Even if no water stress have been observed, other stresses can have consequences upon trees. The first stress could be waterlogging. The water table and the soil compacity implies additive energetic costs to trees, because they need to maintain functioning roots during winter et to rebuild a part of the root system in spring. Repeated caterpillars attacks also imply energy losses and therefore contribute to tree growth limitation and mortality.
Acknowledgements: The authors would like to thank Pierre Lhoir, Frédéric Hardy, Guido Rentmeesters, Louis Gerlache and Patrick Gross for their technical assistance in the field and in the laboratory.

\section{REFERENCES}

[1] Aussenac G., Rainfall interception by the canopy, Ann. Sci. For. 25 (1968) 135-156.

[2] Aussenac G., Forêts et eaux : relations entre écosystèmes forestiers et ressources en eau, in: La gestion durable des forêts : contribution à la recherche, INRA mensuel 12, 1996.

[3] Aussenac G., Granier A., Effects of thinning on water stress and growth in Douglas-fir, Can. J. For. Res. 18 (1988) 100-105.

[4] Aussenac G., Granier A., Naud R., Influence d'une éclaircie sur la croissance et le bilan hydrique d'un jeune peuplement de douglas, Can. J. For. Res. 12 (1982) 222-231.

[5] Aussenac G., Granier A., Bréda N., Effets des modifications de la structure du couvert forestier sur le bilan hydrique, l'état hydrique des arbres et la croissance, Rev. For. Fr. XLVII (1995) 54-62.

[6] Bernier P.Y., Bréda N., Granier A., Raulier F., Mathieu F., Validation of a canopy gas exchange model and derivation of a soil water modifier for transpiration for sugar maple (Acer saccharum Marsch.) using sapflow density measurements, For. Ecol. Manage. 163 (2002) 185-196.

[7] Black T.A., Kelliher F.M., Processes controlling understorey evapotranspiration, Phil. Trans. Roy. Soc. London B 324 (1989) $207-$ 231.

[8] Bréda N., Granier A., Aussenac G., Effects of thinning on soil and tree water relations, transpiration and growth in an oak forest (Quercus petraea (Matt.) Liebl.), Tree Physiol. 15 (1995) 295-306.

[9] Denmead O.T., Bradley E.F., Flux gradient relationships in a forest canopy, in: Hutchinson B.A., Hicks B.B. (Eds.), The ForestAtmosphere interactions, D. Reidel, Hinghamp, 1985, pp. 421-442.

[10] FAO, ISSS Working Group Reference Base. World Reference Base for Soil Resources: Keys to Reference Soil Groups of the World, World Soil Resource Report No. 84, FAO (1998), Rome, 88 p.

[11] Granier A., Évapotranspiration des forêts, C.R. Acad. Agric. Fr. 82 (1996) 119-132.

[12] Granier A., Bréda N., Modeling canopy conductance and stand transpiration of an oak forest from sap flow measurements, Ann. Sci. For. 53 (1996) 537-546.

[13] Granier A., Loustau D., Saugier B., Berbigier P., Bilan hydrique de deux peuplements de pin maritime dans les Landes : évaluation des flux des strates ligneuse et herbacée et de leur variabilité, in ATP PIREN, Influence à l'échelle régionale des couvertures pédologiques et végétales sur les bilans hydriques et minéraux du sol, Rapport final, 1989, pp. 287-315.

[14] Granier A., Bobay V., Gash J.H.C., Gelpe J., Saugier B., Shuttleworth W.J., Vapour flux density and transpiration rate comparisons in a stand of maritime pine (Pinus pinaster Ait.) in Les Landes forest, Agric. For. Meteorol. 51 (1990) 309-319.

[15] Grelle A., Lundberg A., Lindroth A., Morén A.-S., Cienciala E., Evaporation components of a boreal forest: variations during the growing season, J. Hydrol. 197 (1997) 70-87.

[16] Henriksen L.H., Rasmussen K.R., Nornberg P., Atmospheric deposition at a wind-exposed edge of an oak forest, Aarhus Geosci. 4 (1995) 73-82.

[17] Hoff C., Rambal S., An examination of the interaction between climate, soil and leaf area index in a Quercus ilex ecosystem, Ann. For. Sci. 60 (2003) 153-161.

[18] Kelliher F.M., Whitehead D., McAneney K.J., Judd M.J., Partitioning evapotranspiration into tree and understorey components in two young Pinus radiata D. Don stands, Agric. For. Meteorol. 50 (1990) 211-227. 
[19] Kelliher F.M., Leunung R., Sculze E.-D., Evaporation and canopy characteristics of coniferous forests and grasslands, Oecologia 95 (1993) 153-163.

[20] Ladekarl U.L., Estimation of the components of soil water balance in a Danish oak stand from measurements of soil moisture using TDR, For. Ecol. Manage. 104 (1998) 227-238.

[21] Ladekarl U.L., Hansen B., og Rasmussen K.R., Maling og vurdering af vandbalancen for lovskov? Skovrejsnings Betydning for Grundvandsdannelsen, ATV-Komiteen Vedrorende Grundvandsforurening, Institute of Geology and Geotechnics, Danish Technical Univ., 1994, pp. 19-40 (in Danish).

[22] Loustau D., Cochard H., Use of a portable transpiration chamber for estimating evapotranspiration in the Molinia caerulea understorey of a maritime pine stand, Ann. Sci. For. 48 (1991) 29-45.

[23] Lüttschwager D., Rust S., Wulf M., Forkert J., Hüttl R.F., Tree canopy and herb layer transpiration in three Scots pine stands with different stand structures, Ann. For. Sci. 56 (1999) 265-274.

[24] Mathieu F., Étude de la transpiration des couverts d'érable à sucre et de sapins baumiers à partir de mesures de flux de sève et de mesures micrométéorologiques : de l'arbre au peuplement, DEA en Fonctionnement physique, chimique et biologique de la biosphère continentale, INA-PG, Paris VI, ENS, 1999, 55 p.

[25] McNaughton K.G., Jarvis P.G., Predicting effects of vegetation changes on transpiration and evaporation, in: Kozlowski T.T. (Ed.), Water deficits and plant growth, VII, NY, Academic Press, 1983, pp. 1-47.

[26] Myneni R.B., Ross J., Asrar G., A review on the theory of photon transport in leaf canopies, Agric. For. Meteorol. 45 (1989) 1-153.

[27] Nizinski J., Saugier B., Mesures et modélisation de l'interception nette dans une futaie de chênes, Acta Oecol. 9 (1988) 311-329.

[28] Penman H.L., Natural evaporation from open water, bare soils, and grass. Proc. R. Soc. Ser. A 193 (1948) 120-145.

[29] Phillips N., Oren R., A comparison of daily representations of canopy conductance based on two conditional time averaging methods and the dependence of daily conductance on environmental factors, Ann. For. Sci. 58 (2001) 217-235.

[30] Roberts J., Pymar C.F., Wallace J.S., Pitman R.M., Seasonal changes in leaf area, stomatal conductance and transpiration from bracken below a forest canopy, J. Appl. Ecol. 17 (1980) 409-422.
[31] Roberts J., Forest transpiration: a conservative process? J. Hydrol. 66 (1983) 133-141.

[32] Rutter A.J., An analysis of evaporation from a stand of Scots pine, in: Sopper W.E., Lull H.W. (Eds.), Forest hydrology, Pergamon Press, Oxford, 1967, pp. 403-417.

[33] Schnock G., Le bilan d'eau et ses principales composantes dans une chênaie mélangée calcicole de haute-Belgique (bois de VirellesBlaimont), ULB, Fac. Sci. labo. de bota-systématique et d'écologie, 1970.

[34] Stewart J.B., Evaporation of a wet canopy of a pine forest, Water Resour. Res. 13 (1988) 915-621.

[35] Ulrich E., Lelong N., Lanier M., Schneider A., Interception des pluies en forêt: facteurs déterminants, Bulletin technique $\mathrm{n}^{\circ} 30$, 1995, pp. 33-45.

[36] Vertessy R.A., Benyon R.G., O'Sullivan S.K., Grobben P.R., Relationships between stem diameter, sapwood area, leaf area and transpiration in a young mountain ash forest, Tree Physiol. 15 (1995) 559-567.

[37] Vincke C., Approche écophysiologique des flux d'eau au sein d'une chênaie pédonculée $(Q$. robur $\mathrm{L}$.) dépérissante sur sol à régime hydrique alternatif, Thèse UCL, 2003, $392 \mathrm{p}$.

[38] Vincke C., Bréda N., Granier A., Devillez F., Evapotranspiration of a declining Quercus robur (L.) stand from 1999 to 2001. I. Trees and forest floor dairy transpiration, Ann. For. Sci. 62 (2005) 503-512.

[39] Vincke C., Delvaux B., Porosity and available water of temporarily waterlogged soils in a Quercus robur (L.) declining stand, Plant Soil 271 (2005) 189-203.

[40] Welles J.M., Norman J.M., Instrument for indirect measurement of canopy architecture, Agron. J. 83 (1991) 818-825.

[41] Wilson K.B., Hanson P.J., Mulholland P.J., Baldocchi D.D., Wullschleger S.D., A comparison of methods for determining forest evapotranspiration and its components: sap-flow, soil water budget, eddy covariance and catchment water balance, Agric. For. Meteorol. 106 (2001) 153-168.

[42] Wullschleger S.T., Meinzer F.C., Vertessy R.A., A review of wholeplant water use studies in trees, Tree Physiol. 18 (1998) 499-512.

To access this journal online: www.edpsciences.org 